the inequality in the inclination of the moon's orbit, and in the motion of her nodes. He determined with new accuracy the astronomical refractions from an altitude of $45^{\circ}$ down to the horizon, where he found it to be $34^{\prime}$; and he made a vast collection of observations on the planets, which formed the groundwork of Kepler's discoveries, and the basis of the Rudolphine Tables."

\section{MINIATURE PHYSICAL GEOLOGY}

T

HERE have appeared from time to time in the columns of NATURE, interesting and instructive letters on the subject of Miniature Physical Geology. May I be allowed to continue this subject, by pointing out a few lessons which may be learnt during spare halfhours on Ramsgate Sands.

Not far to the east of the harbour, there bubbles up a little stream, which, when the tide is low, flows for a considerable distance over the sands before it reaches the sea. Small as it is, this offers an excellent miniature examiple of a large river, and from it several things may be learnt. In the first place the river, when carefully watched, is seen repeatedly, and with more or less rapidity, to change its course. This is effected by the deflection, from some cause or other, of the inain course of the stream against one bank; the result of which is that the bank is forced to recede, and, as it does so, it ceases to be a shelving slope, and becomes a tiny cliff of greater or less relative height. This bank continues to be rapidly undermined by the action of the stream, and the upper portions, now and again, topple over, with a little splash, into the water, in a manner with which those who have travelled on the Mississippi are well acquainted. In this way a bold curve is formed, which increases in length downstream.

In the meanwhile, on the opposite shore of the river, sand is deposited, and, as the river cuts its way downwards, this portion is left high and dry.

Butt, ere long, the deep water channel shifts-often rapidly, and without apparent cause-and the miniature river tends to resume a straight course; it recedes from its bank cliffs, and soon a träct of comparatively level dry land separates these banks from the stream. After advancing, however, for a while in this direction, until it there forms a curve similar to the one described above, it once more swings in the direction of its former course; until, by a continuance of the same processes, a broad valley is formed, with beautifully-marked river terraces on either side, showing the length of swing of the river on each occasion that it oscillates to and fro.

In the midst of the stream sand islands are from time to time formed, partly by the deepening of the main channel on one side or the other ; but; no sooner has the sand of which they are composed become dry, than the treacherous stream ccmmences the destruction of that Which itself had prodiced.

This is exactly what is continually taking place in the Delta areas of most great rivers. In the Pará branch of the Amazions a large island (Parraqueet Island) has, within the last quarter of a century, completely disappeared. The lhla Nova has arisen, and is now covered with a luxuriant vegetation.

During the repeated changes in the course of our miniature river, it is possible to watch the deposition of a layer of coarse sand on the partially-eroded surface of a bed of finer material, and it is interesting and instructive to notice how great a body of the coarse material is dragged along the bottom. Even in the most sluggish of my miniature streams the sand-grains might be seen rolling over and over each other as they travelled seawards.

In the more muddy flats of Pegwell Bay, I, on one occasion, had an oppoitunity of witnessing the formation of that which is known on the Mississippi as a "cut-off" The miniature stream bent round in a great loop, and as the flow of the water caused the concave banks to recede, the loop was gradually converted into a circle of water, and, the main stream flowing through the shortest course left a "horse-shoe" lake, which was in time almost completely shut off from the miniature river.

Perhaps one of the most interesting of these spare half-hours may be spent in watching the formation of deltas. Numbers of these miniature rivers flow into pools, which are miniature seas or lakes. I have often seen one of the streams in the course of an hour fill up a considerable bay, and push its delta far out to sea. The grains of sand, when they come to rest in the pool, form a slope of very constant angle, which, by a number of measurements, 1 found to be $40^{\circ}$ for coarse sand, and $34^{\circ}$ for fire sand, the average angle being $36^{\circ}$. By watching the advance of the delta, the formation of false bedding may be seen in actual progress. But these pools, ot miniature seas, which lie in depressions in the chalk, offer a field for the study of marine denudation: Orie may see, for instance, the waves advancing over a newly: formed delta, planing off the upper portion, and forming tiny cliffs of delta material, but leaving the deeper parts of the slope of the deposit intact.

Again, during gentle and steady breezes one may see the formation of drift-currents. I remember watching with interest such a current, which flowed between tiny chalk cliffs through the straits which separated two miniature seas; the most instructive point being that the finer grains of sand at the bottom of the straits $s_{j}$ where the water was some 7 inches deep, were rolling over each other in such a manner as to prove the existence of an under-current setting in the opposite direction to that in which the surface-current was flowing.

There are many other lessons which may be learntsuch as the formation of fan-deposits (similar to those so plentiful in the Rhone valley and elsewhere in Switzerland), which are formed at the foot of the miniature chalk mountains. that stand out from the sand; and the stoppage of the sand ripples, or miniature sand dunes; by the tiniest stream, reminding us of the way in which the Nile has preserved Egypt from total obliteration by this material ; but I have already occupied enough of your space.

My object in drawing attention to such matters of ordinary observation is to induce students of physical geology to go out and observe these things for themselves. If after a morning's study of Lyell's "Principles," the young geologist will devote an hour's careful observation to miniature physical geology, with sketch and note-book in hand, he will find that his conceptions have a reality and a solidity which could not have been evolved in the study at home, while at the same time he will find it more easy to follow, when he shall have the opportunity, the workings of nature on a grander scale.

\section{LLOYD MORGAN}

\section{TESTIMONIAL TO MR. DARWIN-EVOLU-} TION IN THE NETHERLANDS

WE have great pleasure in printing the following correspondence :-

\section{To the Editor of NATURE.}

Utrecht, February 20,1877

On the sixty-eighth birthday of your great countryman, Mr. Charles Darwin, an album with 217 photographs of his admirers in the Netherlands, among whom are eightyone Doctors and twenty-one University Professors, was presented to him. To the album was joined a letter, of which you will find a copy here inclosed, with the answer of Mr. Darwin. 
I suppose you will like to give to both letters place in your very estimable journal, and therefore I have the honour to forward them to you.

\section{P. HARTING,}

Professor, University, Utrecht.

\section{Rotterdam, 6th February, 1877}

SIk, - In the early part of the present century there resided in Amsterdam a physician, Dr. J. E. Doornik, who, in 1816 , took his departure for Java, and passed the remainder of his life for the greater part in India. His name, though little known elsewhere than in the Netherlands, yet well deserves to be held in remembrance, since he occupies an honourable place among the pioneers of the theory of development. Among his numerous publications on natural philosophy, with a view to this, are worthy of mention his "Wijsgeerig-natuurkundig onderzoek aangaande den vorspronkelijken mensch en de vorspronkelijke stammen van deszelfs geslacht" ("Philosophis Researches concerning Original Man and the Origin of his Species"), and his treatise, "Over het begrip van levenskracht uit een geologisch oogpunt beschouwd" ("On the Idea of Vitality considered from a Geological Point of View "). The first already appeared in 1808 ; the latter, though written about the same time, was published in 1816 , together with other papers more or less similar in tendency, under the title of "Wijsgeerig-natuurkundige verhandelingen" " "Treatises on the Philosophy of Natural History"). In these publications we recognise Doornik as a decided advocate of the theory that the various modifications in which life was revealed in consecutive times originated each from the other. $\mathrm{He}$ already occupies the point of vantage on whicb, shortly afterwards, Lamarck, with reference to the animal kingdom, and in his wake, Prévost and Lyell, with respect to the geological history of our globe, have taken their stand.

Yet the seeds scattered by Dr. Doornik did not take root in fertile soil. It is true that a Groningen professor, G. Bakker, combaied at great length some of his arguments regarding the origin of man; it attracted but little public attention, and they soon passed into oblivion.

A generation had passed away ere the theory of evolution began to attract more attention in the Netherlands. The impulse was given by the appearance of the well-known work, "Vestiges of the Natural History of Creation," of which a Dutch translation was published in 1849 by Dr. T. H. van den Broek, Professor of Chemistry at the Military Medical College in Utrecht, with an introductory preface by the celebrated chemist, Prof. G. T. Mulder, as well known in England as elsewhere. This work excited a lively controversy, but its opponents were more numerous than its partisans. Remarkably enough, it found more favour with the general public, and especially with some theologians of liberal principles, than with the representatives of the natural sciences. The majority of zoologists and botanists of any celebrity in the Netherlands looked upon the writer's opinions as a chimera, and speculated on the weaker points rather than on the merits of the work. Notwith. standing, this presented no obstacle to a comparative success, and in 1854 , even a thlrd edition of the translation was published, enriched by the translator with numerous annotations.

Among the few Dutch savants to recognise the light which the theory of development spreads over creation, must be nentioned two Utrecht professors, viz, F. C. Donders and P. Harting. The former, in his inaugural address pronounced in I848, "De Harmonie van het dierlijk leven, de openbaring van wetten" ("The Harmony of Animal Life, the Revelation of Laws"), expressed his opinion that, in the gradual change of form consequent upon change of circumstances, may lie the cause of the origin of differences which we are now wont to designate as species. The latter, in the winter of 1856 , delivered a series of lectures before a mixed audience, on "The History of Creation," which he published the following year under the title of "Voorwereldlijke Scheppingen" "Antemundane Creations"), with a diffuse supplement devoted to a critical consideration of the theory of development. Though herein he came to a standstill with a "non liquet," yet it cannot be denied that there gleamed through it his prepossession in favour of a theory which several years later his famed and learned colleague, J. van der Hoeven, Professor at Leyden, making a well-known French writer's words his own, was accustomed to signalise as an explanation, "de l'inconnu par l'impossible."

In 1858 your illustrious countryman, Sir Charles Lyell, was staying for a few days in Utrecht. In the course of conversa. tions with this distinguished savant on the theory of develop. ment, for which Lyell himself, at least in his writings, had shown himself no pleader, the learned of this country were first. made observant of what had been and what was being done in that direction in England. He attracted atterition to the treatise of Wallace in the Journal of the Linnean Society, and related how his friend Darwin had been occupied for years in an earnest study of this subject, and that ere long a work would appear from his pen, which, in bis opinion, would make a considerable impression. From these conversations it was evident that Lyeil himself was wavering. In the following edition of his "Principles of Geology," he declared himself, as we know, a partisan of the hypothesis of development, and Prof. Harting speedily followed in the same track. In his "Algemeene Dierkund:" ("General Zoology "), published in 1862 , he was able to cleclare himself with full conviction a partisan of this hypothesis. Also another famous savant, Miquel, Professor of Botany at Utrecht, who had previously declared himself an opponent of the Theory of Development, became a convert to it in his later years, for although this is not expressed in his published writings, it was clearly manifest in his private conversation and in his lectures. To what must this conversion be attributed? With Harting and Miquel, as well as with Lyell and so many others in every country of Europe, this was the fruit produced by the study of your "Origin of Species," published in 1859, which first furnished one vast basis for the theory of development. That work, translated into Dutch by Dr, F. C. Winkler, now con. servator of the Geological, Mineralogical, and Paleontological collections in "Feyler's Foundation" at Haarlem excited great and general interest. It is trie that a theory, striking so keenly and so deep at the roots of existing opinions and prejudices, could not be expected at once to meet with general approbation. Many even amongst naturalists offered vehement opposition. Prof. J. van der Hoeven, bred up as he was in the school of Cuvier, endeavoured to administer an antidote for what he re. garded as a baneful poison by translating into our tongue Hopkins' well-known article in Fraser's Magazine. However, neither this production nor the professor's infuence over his students could withstand the current, especially when, after his death, the German zoologist, Prof. Emil Selenka, now Professor of Zoology at Erlangen, was appointed at Leyden. A decided advocate of your theory, he awakened in the younger zoologists a lively enthusiasm, and founded a school in which the conviction survives that the theory of development is the key to the explana* tion of the History of Creation.

In Utrecht, Prof. Harting, with convictions more and more decided, was busy in the same direction; and Selenka's successor in Leyden, Prof. C. K. Hoffmann, did not remain in the rear. Other names, among which are Groningen and Amsterdam professors, might here be cited. By the translation of your "Descent of Man" and "The Expressions of the Emotions in Man and Animals," with copious explanatory notes and by various original papers and translations treating on your theory, Dr. Hartogh Heys van Zouteveen has also largely contributed to the more general spread of your opinions in the Netherlands.

To testify how grenerally they are held in esteem among thie younger zoologists and botanists, and more and more obtain among professors of analogous branches in this country, we might refer to a multitude of less important papers and articles in the periodicals.

This, however, we deem superfluous, since by offering for your acceptance an album, containing the portraits of a number of professional and amateur naturalists in the Netheriands, we offer a convincing proof of our estimation of your indefatigable encleavours in the promotion of science and our admiration of you, Sir, as the cynosure in this untrodden path. We recognise with pleasure Dr. Hartogh Heys van Zouteveen as the primary mover of such a demonstration of our homage. The execution, how ever, devolved upon the directors of the "Netherland Zoological Society," who reasoned that, with the presentation of this unpretending mark of esteem, a few words on the History of the Theory of Development in the Netherlands would not be entirely unacceptable, the more so, since this historic sketch clearly shows that, albeit some ideas in that direction had already been suggested here, yet to you alone reverts the honour of having formed by your writings a school of zealous and convinced partisans of the theory of development.

Among the names in the accompanying list you will observe several professors of Natural History, Anatomy, and Physiology at the three Dutch Universities, the "Atheræum Illustre" of Amsterdam, and the Polytechnical Academy of Delft, the Con- 
servators of the Zoological Museums, the Directors of the Zoological Gardens, and several lecturers on zoology and botany at the High Burghal Schools.

Accept, then, Sir, on your sixty-ninth birthday, this testimony of regard and esteem, not for any value it can have for you, but as a proof, which we are persuaded cannot but afford you some satisfaction, that the seeds by you so liberally strewn have also fallen on fertile soil in the Netherlands.

\section{We are, Sir, \&c.,}

The Directors of the Netherlands Zoological Society,

(Signed) President, A. A. Van Bemmeltin Secretary, H. T. VETH

\section{The following is Mr. Darwin's reply :-}

\section{Down, Beckenham, February I2}

SrR, - I received yesterday the magnificent present of the album, together with your letter. $\Upsilon$ hope that you will endeavour to find some means to express to the 217 distinguished observers and lovers of natural science, who have sent me their photographs, my gratitude for their extreme kindness. I feel deeply gratified by this gift, and I do not think that any testimonial more honourable to me could have been imagined. I am well aware that my books could never have been written, and would not have made any impression on the public mind, had not an immense amount of material been collected by a long series of admirable observers, and it is to them that honour is chiefly due.

I suppose that every worker at science occasionally feels depressed, and doubts whether what he has published has been worth the labour which it has cost him; but for the remaining years of my life, whenever I want cheering, $I$ will look at the portraits of my distinguished co-workers in the field of science, and remember their generous sympathy. When I die the album will be a most precious bequest to my children. I must further express my obligation for the very interesting history contained in your letter of the progress of opinion in the Netherlands, with respect to evolution, the whole of which is quite new to me. I must again thank all my kind friends from my heart for their ever-memorable testimonial, and

$$
\begin{aligned}
& \text { I remain, Sir, } \\
& \text { Your obliged and grateful servant, } \\
& \text { (Signed) CHARLES R. DARWIN }
\end{aligned}
$$

\section{THE NORWEGIAN NORTH-SEA EXPEDITION $O F{ }_{1876^{-}}$}

\section{Zoological Researches}

AONG the various scientific objects of our expedition the examination of the biology of those parts of the ocean which we traversed was one of the most important. We had with this view equipped ourselves in the best way with all the apparatus required for the purpose (dredges, trawl-nets, swabs, sieves, \&c.), chicfly after the newest English models, a considerable quantity of ropes of various kinds, and heavy iron weights to hold the apparatus to the bottom were also stowed away in the hold of the vessel. There was besides procured a large quantity of glass vessels of different sizes and kinds, from small test-tubes to cylinders a foot in diameter, and a considerable stock of spirits for preserving the specimens that raight be collected.

That the zoological material that might be brougint up with the apparatus we have named might be arranged and the preliminary examinations made, which would be of great importance for the later working out, we considered it indispensable that as many zoologists as possible should accompany the expedition; we also thought it right that a skilful artist should always be at hand. The zoological party consisted of Overlæge Danielssen, Grosserer Friele, and myself, and as artist we were fortunate enough to engage Herr Schiertz, landscape-painter, whose practised pencil and keen, all-embracing faculty of observation were exceedingly useful to us. There is a series of masterly-coloured pictures from his hand which will be a true ornament to the zoological treatises, which in course of time will be published on the work of the expedition.

The zoological work was divided in this way:--Overlæge Danielssen and Dr. Koren undertook the Echinodermata, Gephyreerna, and Corals; Grosserer Friele, the Mollusca; Dr.

$$
{ }^{x} \text { Ey Prof. G. D. Sars. From Dagbladet, January } 26 \text { and } 27 .
$$

Hansen, the Annelida ; and I myself the other classes, the Crustacea, Pycnogonida, Polyzoa, Hydroida, Spongia, together with the lowest organisms standing on the boundary line between the animal and vegetable kingdoms (Foraminifera, Radiolaria, and Diatomacea), and that department of the researches which eventually concerns our salt-water fisheries. We have all been occitpied for a considerable time in working out each his own portion of the collected material. But as this has been extraordinarily abundant, it has not been possible for any of us to bring his examination to a conclusion so that a detailed account of it can be given. As, besides, the more special results will be reserved for the collective work, which it is proposed to publish when the expeditions are concluded, it will be sufficient here to state some of the most important results of the expedition. It may also here be mentioned that these researches, carried on far out in the open sea from a comparatively small vessel, and at depths approaching 2,000 fathoms, are, even under the most favourable circumstances, attended with extraorclinary difficultles, and occupy a comparatively long time. That we, notwithstanding the exceedingly unfavourable state of the weather during the expedition, were able to obtain such an abundance of zoological material, is due to the skilful and intelligent way in which the work was carried out by Lieut. Petersen, to whom Capt. Wille's command was given over.

During our expedition we had in all employed the dredge from the vessel sixteen times, the trawl-net twelve times, both these together twice, and the swabs but once; there were thus no fewer than thirty-one separate casts, and of these only a few were unsuccessful, while most of them gave very satisfactory results. A net was also employed for examining the marine animals occurring in the upper stratum. Boat dredgings were also undertaken in Sogne Fiord, at Husoe, at Thorshaven in the Frroe Islands, and in the harbour at Reykjavik. Without entering on any detailed specification of the numerous animal forms thus brought from the depths of the sea, I will merely state that there are interesting species, new to science, of nearly all classes, of which complete descriptions and drawings will by-and-by be published.

The greatest depth reached during the expedition was about 2,000 fathoms, almost half-way between Norway and Iceland; there were several casts at depths of over I, 000 fathoms. The zoological researches were begun in Sogne Fiord, where the considerable depth of 650 fathoms was reached, the greatest depth which up to that time had been examined on our coasts. We found here the common deep-sea fauna known from earlier researches, viz., of Hardanger Fiord, and various rarities were collected; among others a well-preserved specimen of the remarkable family, Brisinga, discovered by Asbjoernsen ( $B$. coronata, G. D. Sars), several specimens of the Priapuloides bicaudata, Danielssen, and great numbers of the beautiful haired Minnida tenuimana, G. D. Sars, of which previously only very few specimens had been found.

Our researches, however, first attained their peculiar interest when we reached the extended barrier that lies along our coast on the west, the uttermost limit of which forms the so-called Havbro. Here below 300 fathoms begins the yet little examined cold area, with a bottom-temperature of from $0^{\circ}$ to $I \cdot 6^{\circ} \mathrm{C}$., and the fauna now, in correspondence with this temperature, exhibit a very peculiar character, totally different from that on our south and west coasts. Seventeen of our casts were in the cold area, and we have thus some idea of the peculiar physical and biological conditions prevailing there.

Over the extensive depression which occupies the greater part. of the expanse of sea between Norway on the one side, and the Froro Islands and Iceland on the other, the bottom below $\mathrm{x}, 000$ fathoms appears everywhere to consist of a very peculiar, loose, but very adhesive, exceedingly light, nearly greyish white clay, which is very strongly calcareous, and, on being washed or passed through a sieve, appears to consist almost exclusively of shells of a little, low organism, belonging to the Foraminifera, Biloculina. We have therefore named this deep-sea clay Biloculina clay, to distinguish it from the kind of clay which occurs in the warm area at a great depth in the Atlantic Ocean, and which is called, after a very different Foraminifer, Globigerina. The Biloculina clay of the cold area contains a larger quantity of lime than the Globigerina clay of the Atlantic. It gives off, when treated with an acid, an uncommonly large quantity of gas, and when it is pressed and dried, it is converted in a short time into a very hard and compact sort of limestone. We have here a complete chalk or limestone formation coming into existence, and the fauna occurring here also bears a considerable impress of 